\title{
CUSTOMERS' AWARENESS, ATTITUDE AND PATRONAGE OF ISLAMIC BANKING IN NIGERIA
}

\author{
Kareem Muritala Kewuyemi*
}

\begin{abstract}
This study examines customers' awareness of Islamic banking products and services in Nigeria and explores their attitude towards them. It also investigates their patronage of the banks. An 18-item questionnaire was designed for businesspersons, Muslims and non-Muslims, to obtain information on issues such as awareness of Islamic banking, loans without interest, collateral security, agency, partnership based on sharing of profits and losses and patronage of an interest free financial system. The results show the willingness of the Muslims and a large number of non-Muslims to patronise Islamic banking products and services. Products and services offered by a large number of the respondents were shari 'ah-compliant. Their readiness to give collateral security, which is neither compulsory nor against the dictates of Islam, indicates their attitude and preparedness to patronise Islamic banks. However, a few non-Muslim respondents state they will not patronise Islamic banking products even if they are profitable and they are the only products in the banking sector in Nigeria. This study will assist promoters of Islamic banks in Nigeria to know where they can establish full-fledged Islamic banks. There is need for the existing and the potential Islamic banks to create more public awareness on Islamic banks.
\end{abstract}

Keywords: awareness, attitude, patronage, Islamic banking, interest, customer, Nigeria

\section{Introduction}

Nigeria as a country covers an area of 927,773 square kilometers. It is an agrarian economy. Its major cash crops include cocoa, rubber, hides and skin, palm produce, cotton, and groundnuts, to mention a few. Its food crops are yam, ice, maize millet etc. (International IDEA, 2001:153). Agricultural products represent a large share of Nigeria's exports. The sector accounts for two-third of total output and employs about 73 percent of the total labour force. Minerals such as tin, coal and columbite also form part of its exports. During the period, visible increases occurred in the living standards of a large number of Nigerian people (Anyanwu, 1993; Ekpo, 1986). It was assumed that the oil boom would further increase the standard of living of Nigeria. The opposite was the case for a large number of people have been living below the poverty line of one dollar per day as a result of corruption and mismanagement. 
Upon introduction of the banking system in 1894 (Ekezie, 2002), one would expect that the poverty level of the people would be reduced because of the belief that people would have access to funds with which they can engage themselves in various professions and commercial activities. This expectation was dashed as a result of high interest rates attached to loans given by the banks. Presently, the average interest rate on loans given out by the Nigerian banks is about 25 percent (CBN Website).

Therefore, many people could not source funds from banks, not only because of the high interest rates, but also their inability to provide collateral. The introduction of Islamic banking on 13 January 2011 gave the poor another opportunity of having access to a cheap source of funds. This is because Islamic banking looks at feasibility studies instead of credit worthiness and interest rates as standards. The poor do not have to get collateral before they can have an easy access to funds in an Islamic financial system. However, collateral may be requested to prevent or reduce moral hazards such as dishonesty and a running away of the entrepreneur. People, particularly the poor with good business experience, but lacking funds to put their business acumen to use can thrive better with this type of banking. It can empower the poor and raise their living standards in a better way than conventional banks can. Both finance users and capital providers benefit in terms of returns (Fuad and Mohammed, 1988).

Going ultra vires is nearly impossible in an Islamic financial system because all the products are asset-backed. For instance, in murābahah, assets, machines, goods, etc. are bought for a person that is interested in this product. So, there is no chance of using the funds for a thing that is not in the business plan. As good as the bank is in relation to the haves and the have-nots, it can only survive if it is patronised by people. Therefore, the feasibility, viability and profitability of Islamic banks depend on the number of customers they can attract. In the light of the above-mentioned reasons, the paper seeks to examine customers' awareness of the bank, explore their attitude towards it and investigate their patronage of the bank. To achieve these objectives, the paper seeks to answer these research questions.

1. To what extent are people ready to accept unlimited liability?

2. Are there Sharī 'ah-compliant products in people's businesses?

3. To what extent are business persons ready to give collateral security before they obtain loans?

4. Are Islamic products being used by business persons inadvertently?

5. Are people ready to patronise Islamic financial institutions?

6. Are Nigerians aware of Islamic banks?

7. If they are, are they ready to patronise it? 
These and other questions will be answered in this paper. Answering these questions, posed to businesspersons, will also assist some cooperatives who plan to establish Islamic micro-finance banks. It should also help existing Islamic financial institutions to innovate products that will assist them in attracting additional customers, both Muslims and non-Muslims.

\section{Literature Review}

Principles of Sharī 'ah govern the operation of Islamic banks. The principles are derived from the Quran, the Sunnah, Qiyās and Ijmā' (Ali, 1986: 17). The principal sources are the first two. The Quran was revealed to the Prophet (Peace be upon him) over a period of about 23 years. No stone was left untouched and unturned in the Quran in relation to all aspects of human life: social, moral, economic and political (Q6:38). As regards the principles of Islamic banking, the Qur'ān discusses them. It must, however, be mentioned that details as regards the operation of Islamic banking are not in the Qur'ân. It only gives the broad principles. Scholars elaborate them with a view to deriving the details of its operation. The second principal source is the sayings and deeds of the prophet (pbuh). The Prophet (pbuh) who was the one who received the revelation directly from Allah through the angel Jibril was in the best position to explain the words of Allah and how they can be applied in our social, political, moral and commercial dealings.

Under an Islamic bank, risks and rewards are shared by depositors and Islamic banks. This is not the case under the conventional banking system. Both risk and rewards are born by the bank. The depositors are only given fixed rates of return. Interest-based loans, which are the credit policy of the conventional bank, are not allowed under Islamic banks. This is because of the prohibition of interest as contained in Q 2:275-279 and other Qur'anic verses. Rib $\bar{a}$ (interest) is prohibited because it is a sure gain without any possibility of loss; i.e. whether the finance user makes a gain or incurs loss, the provider of funds must get both his capital and the interest on it. The culture of brotherhood and sympathy is totally negative as regards getting back the loan on interest. Therefore, from the moral and spiritual points of view, it is clearly seen that interest-based loans are based on selfishness, greed and hard-heartedness. In Islam, money cannot give birth to money. Aristotle likened money to a barren hen, which could not lay eggs until money is used when he enumerated the nature of money. In the words of Aristotle, "a piece of money cannot beget money" (Aristotle Book 1, Chapter $\mathrm{X}, 1258)$. In relation to barrenness of money, St. Thomas Aquinas declared that the taking of usury (interest) for money lent was unjust in itself because this was to sell what did not exist (Vaish, 2000: 341). Islamic banking products include 
murābahah, mushārakah, 'ijārah, 'istisnā', bay'un mu'ajjal and sukūk. These products can be used by both Muslims and non-Muslims. Egboro (2011) in his work on interest-free banking in Nigeria, welcomes both Islamic as well as Christian banking, as he believes that interest-free banking is for both Muslims and Christians. The only difference between the two forms of banking is that the latter prohibits interest to some extent while in the former not only are all forms of interest prohibited totally but also other Sharī'ah non-compliant products and services such as pork, alcoholic drinks and pornography are totally prohibited. The fear of many people is that Islamic banks may discriminate against nonMuslim. The fear is unfounded. The perspectives and attitudes of people, both existing and potential customers towards Islamic banking differ. In countries such as Kuwait, Sudan and Pakistan, religion is the main attraction of Islamic banking while the main attractions for non-Muslims in those countries are the bank's products and services, good customer relations, and effective and efficient service (Rammal \& Zurbruegg, 2007).

Alao (2012) in his study titled "Islamic Banking: The Controversy over nonInterest Banking System in Nigeria" believes that the principles of Islamic banking may challenge sharp practices in conventional commercial banks in Nigeria. He also believes that principles of interest-free banking as contained in the Bible predated Islam. He then warned the operators of the bank not to discriminate against the Christians while urging the Christians to wake up from their slumber and establish similar banks to assist their people. From the researches conducted in Mauritius (Dineshwar 2013), Pakistan and Turkey (Okumus, 2005), Thailand (Lateh et al, 2009), South Africa (Priviledge, 2014), Malaysia (Thambiah et al 2011, and Australia (Rammal and Zurbrueg 2006) to mention a few, there is a high level of awareness of conventional banking products such as current accounts and savings accounts. It was also noted that the only knowledge a large number of non-Muslim respondents in those countries had in relation to Islamic banking principles was the prohibition of interest in the operation of Islamic banking. They had little or no knowledge of the Islamic banking products and services.

\section{Methodology}

In this study, the research method used was the survey. The major instrument used for gathering data was the questionnaire, though some key people were also interviewed. An 18-item structured questionnaire was designed to elicit information from businesspersons on issues such as awareness of Islamic banking, loan without interest, collateral security, agency, partnership based on sharing of profits or losses and patronage of interest-free financial system. We decided to use a questionnaire as our instrument because it is the most productive 
when a researcher needs to reach out to a large number of respondents. In fact, the cost of conducting survey questionnaires is lower than any other forms of research such as face-to-face interviews.

In measuring attitudes, feelings, perceptions, opinions and stimuli, Likert type scales, also called summated rating scales, are used in this study. This is because it is one of the three methods that can measure objectively to some extent, the subjective and abstract concepts that are usually embedded in the feelings and perceptions of people (Nnamd 2004: 58) towards Islamic banking. Two other methods are: Thurstone equal appearing interval scales and cumulative scales. Using this method, the researcher was able to analyse the results and make deductions and conclusions therefrom. In this study, respondents were asked to rate their attitude towards Islamic banking in Nigeria. Using a Likert scale of 5 points, the degree of agreement by the respondents to each of the items in the questionnaire is measured. We calibrated the scale into strongly agreed (SA), agreed (A) undecided (U), disagreed (D) and strongly disagree (SD) with the value of 5, 4, 3, 2, and 1 respectively. The numbers have no intrinsic value.

\section{Population}

The population studied consisted of Muslims and non-Muslims in major commercial centres in Nigeria: Ibadan, Lagos, Uyo, Aba, Kaduna and Kano. The business persons surveyed included market women and men, private employees, contractors, and government employees. It was assumed that they would be able to give their opinions as regards the feasibility, viability and profitability of an interest-free financial system in Nigeria.

\section{Administration of instruments}

The researcher employed research assistants who administered the questionnaire in major commercial centres in Nigeria: Ibadan, Lagos, Aba, Uyo, Kano and Kaduna. These places were chosen because they gave a good representation of the other areas not covered. Business persons were provided 1,100 copies of the questionnaire. The completed and returned copies were 1,067. The response rate was 97.00 percent

$$
\frac{1,067 \times 100}{1,100}=97.00 \%
$$




\section{Analysis of Data and Discussion of Findings}

In this section, we present the findings of the research as regards customers' awareness, attitude and patronage of Islamic banking products. According to the Oxford Advanced Learner's Dictionary, awareness means "knowing that something exists and is important," and "being interested in something" (Hornby, 2005:88). In the real sense, awareness is very important because one cannot put an attitude towards an object if one does not have knowledge of the object. It is also not possible to make a decision whether one will patronise it or not until one has the knowledge of its operation. So, awareness of a particular product will make a potential buyer of the product seek knowledge about it with a view to gaining complete information about the product. Having gained the knowledge, he will decide whether to buy the commodity or patronise the business. If after a trial he finds the product suitable for his taste, he adopts it. Therefore, the paper examines customers' awareness of Islamic banking because it determines their patronage. The probability of patronising the bank is very high if a person is aware and understands its features.

What do we really mean, when we use the word "attitude"? In defining an attitude, a standard and acceptable definition given by Fred (1973: 495) is considered. He has defined an attitude as "an organised predisposition to think, feel, perceive and behave towards a referent or cognitive object". Albarracin (2005: 4) viewed attitude as a psychological tendency to view a particular object or behaviour with a degree of favour or disfavour. Attitude may also mean the way that you think and feel about somebody or something; the way you behave towards somebody or something that shows how you think and feel (Hornby, 2005: 81). It can be inferred from these definitions that people develop various attitudes towards objects, people and events they encounter. They may be positive or negative.

The data obtained from the questionnaire attached as an appendix were analysed here to provide answers to the research questions earlier itemised and the findings of the research were also discussed. 
Table 1: Respondents’ Demographic Profile

\begin{tabular}{|c|l|c|c|}
\hline & & Frequency & Percent \\
\hline \multirow{2}{*}{ Gender } & Male & 437 & 41.0 \\
& Female & 630 & 59.0 \\
& Total & 1067 & 100 \\
& & & \\
\hline Religion & Islam & 154 & 14.4 \\
& Christianity & 882 & 82.7 \\
& Judaism & 17 & 1.6 \\
& Others & 14 & 1.3 \\
& Total & 1067 & 100 \\
& & & \\
\hline Work & Owner & 227 & 26 \\
& Agent & 755 & 70.8 \\
& Apprentice & 17 & 1.6 \\
& Others & 18 & 1.7 \\
& Total & 1067 & 100 \\
\hline Level of & No formal education & 27 & 2.5 \\
Education & Primary & 54 & 5.1 \\
& Secondary & 229 & 21.5 \\
& NCE/OND & 624 & 58.5 \\
& BA/BSc/HND & 133 & 12.5 \\
& Total & 1067 & 100 \\
& & & \\
\hline
\end{tabular}

From the descriptive result, the demographic profile in Table 1 indicates that 41 percent of the respondents were males while 59 percent respondents were females. The descriptive analysis revealed that Christian respondents were 882 i.e. 82.7 percent while 154 respondents were Muslims. The reason for giving Christians a larger number of the questionnaire was to ascertain their feelings towards Islamic banking. As regards Muslims, we have assumed that, all things being equal, virtually all of them would patronise Islamic banking because of the affiliation of their religion to the bank.

With regard to work, the highest number (70.8 percent) of the respondents showed that they were agents while 26 percent indicated they were business owners. A number of Islamic banking products need agents to work with principals, i.e. business owners. This high percentage is appropriate. Frequency and percentage analysis showed that 58.5 percent of the respondents were Nigeria Certificate in Education (NCE)/Ordinary National Diploma (OND) holders followed by holders of Senior School Certificate Examination (SSCE) (21.5 percent). 12.5 percent were holders of Bachelor of Arts (B.A)/Bachelor of Science (BSc)/ Higher National Diploma (HND) certificates. These 3 sets of people involved 
were categorised in their working age group. Involvement of these people in the administration of questionnaire would indicate whether Islamic banking would be acceptable and patronised because they would form large numbers of people that have purchasing power and an educational background to patronise the bank.

Table 2: Taking interest free loan and bearing of unlimited liability

\begin{tabular}{|l|l|l|l|l|}
\hline \multicolumn{1}{|c|}{ Description } & Frequency & Percent & $\begin{array}{c}\text { Valid } \\
\text { Percent }\end{array}$ & $\begin{array}{l}\text { Cumulative } \\
\text { Percent }\end{array}$ \\
\hline $\begin{array}{l}\text { I can take loan } \\
\text { without interest }\end{array}$ & & & & \\
SA & 339 & 31.8 & 31.8 & 31.8 \\
A & 471 & 44.1 & 44.1 & 75.9 \\
SD & 91 & 8.5 & 8.5 & 84.4 \\
D & 85 & 8.0 & 8.0 & 92.4 \\
U & 81 & 7.6 & 7.6 & 100.0 \\
Total & 1067 & 100.0 & 100.0 & \\
\hline I can accept & & & & \\
unlimited liability & & 6.6 & 6.6 & 6.6 \\
SA & 70 & 19.0 & 19.0 & 25.6 \\
A & 203 & 21.6 & 21.6 & 47.2 \\
SD & 231 & 24.3 & 24.3 & 71.5 \\
D & 259 & 28.5 & 28.5 & 100.0 \\
U & 304 & 100.0 & 100.0 & \\
Total & 1067 & & & \\
\hline
\end{tabular}

\section{Loans without interest and bearing of unlimited liability}

Research question one: To what extent are people ready to accept unlimited liability? Items 1 and 2 of the questionnaire attached as an appendix provided answers to this research question. Our respondents were asked whether they could take loans without interest or they preferred paying interest to sharing profit and loss. As can be seen from Table 2, a large number of our respondents (75.9) among business persons indicated their readiness to take loans without interest. By implication, they should also be ready to bear unlimited liability if losses were incurred. Bearing unlimited liability is one of the characteristics of interest-free financial system. A large number of our respondents (74.4 percent) 
were not ready to bear such a burden. This is understandable if one considers our corrupt environment where many people are not honest. If it is established and people are seen to be honest, they may not mind bearing unlimited liability arising from business transactions of an interest-free bank.

Are there Sharī'ah compliant products in people's businesses? To what extent are businesspersons ready to give collateral security before they obtain loans? Items 4-8 of the questionnaire provided answers to these research questions.

Table 3: Willingness and preparedness to accept Islamic banking product

\begin{tabular}{|l|l|l|l|l|}
\hline \multicolumn{1}{|c|}{ Description } & Frequency & Percent & $\begin{array}{c}\text { Valid } \\
\text { Percent }\end{array}$ & $\begin{array}{l}\text { Cumulative } \\
\text { Percent }\end{array}$ \\
\hline $\begin{array}{l}\text { One should be able } \\
\text { to expose the secrets } \\
\text { of one's business for } \\
\text { monitoring }\end{array}$ & & & & \\
SA & & & & \\
A & 319 & 29.9 & 29.9 & 29.9 \\
SD & 256 & 24.0 & 24.0 & 53.9 \\
D & 173 & 16.2 & 16.2 & 70.1 \\
U & 227 & 21.3 & 21.3 & 91.4 \\
Total & 92 & 8.6 & 8.6 & 100.0 \\
\hline Keeping proper accounts & 1067 & 100.0 & 100.0 & \\
of business is necessary & & & & \\
SA & & & & \\
A & 70 & 6.6 & 6.6 & 6.6 \\
SD & 203 & 19.0 & 19.0 & 25.6 \\
D & 231 & 21.6 & 21.6 & 47.2 \\
U & 259 & 24.3 & 24.3 & 71.5 \\
Total & 304 & 28.5 & 28.5 & 100.0 \\
\hline Every business should be & 1067 & 100.0 & 100.0 & \\
Shari'ah compliant & & & & \\
SA & 203 & 19.0 & 19.0 & 25.6 \\
A & 231 & 21.6 & 21.6 & 47.2 \\
SD & 304 & 28.5 & 28.5 & 71.5 \\
D & 1067 & 100.0 & 100.0 & 100.0 \\
U & & & \\
Total & & & \\
\hline
\end{tabular}




\begin{tabular}{|l|l|l|l|l|}
\hline $\begin{array}{l}\text { I can sell pork, alcoholic } \\
\text { drinks, dead animals and } \\
\text { the likes }\end{array}$ & & & & \\
SA & 63 & 5.9 & 5.9 & 5.9 \\
A & 63 & 5.9 & 5.9 & 11.8 \\
SD & 556 & 52.1 & 52.1 & 63.9 \\
D & 319 & 29.9 & 29.9 & 93.8 \\
U & 66 & 6.2 & 6.2 & 100.0 \\
Total & 1067 & 100.0 & 100.0 & \\
\hline I can give collateral & & & & \\
security if am given loan & & & & \\
& & & & \\
SA & 310 & 5.9 & 5.9 & 5.9 \\
A & 510 & 5.9 & 5.9 & 11.8 \\
SD & 37 & 52.1 & 52.1 & 63.9 \\
D & 71 & 29.9 & 29.9 & 93.8 \\
U & 139 & 6.2 & 6.2 & 100.0 \\
Total & 1067 & 100.0 & 100.0 & \\
\hline
\end{tabular}

\section{Willingness and preparedness to accept Islamic banking products.}

Research questions two and three: Effective supervision and monitoring of businesses can reduce costs and increase profitability. As shown in Table 3, the frequency analysis revealed that nine hundred responded kept proper accounts of their business and about a half of the respondents ( 53.9 percent) were ready to expose the operational activities of their business for monitoring. This attitude is in line with the dictate of Islam as contained in Q2: 282. Partners in business are advised to write down the transactions between themselves. If they cannot, they should call a scribe to do that on their behalf.

An interest-free financial system does not only prohibit interest in its operation, Sharī'ah non-compliant products such as pork, wine, etc are also frowned upon. Our result shows that products and services offered by many respondents were shari' 'ah compliant (88.2 percent). The implication of this is that there are more than enough sharī'ah compliant products that interestfree financial institutions can make use of. To test the understanding of our respondents with regard to Sharī'ah compliant products, a follow-up question was put to them, whether they sell pork, alcoholic drinks etc. Many of them are not interested in the above-mentioned products which are not Shari' $a h$-compliant. It must be mentioned that it is not only the charging of interest that makes Islamic 
banking different from the conventional banks. Islamic banks should not deal in the above-mentioned products and other Shari 'ah non-compliant ones as stated in the Quran and the Sunnah (Q 2:168, 172, 219; Q 5:90-91).

Providing collateral as security is neither compulsory nor against Sharī'ah. However our results show that our respondents ( 77 percent) are ready to provide collateral to show their readiness to pay back loans without interest. In case they cannot pay back the loan, the banks can sell the security to recoup their funds. Are Islamic products being used by businesspersons inadvertently? Items 3, 9-17 of the questionnaire provided answers to this research question

Table 4: Attitude of respondents to the use of Islamic banking products and services

\begin{tabular}{|l|l|l|l|l|}
\hline & Frequency & Percent & $\begin{array}{c}\text { Valid } \\
\text { Percent }\end{array}$ & $\begin{array}{c}\text { Cumulative } \\
\text { Percent }\end{array}$ \\
\hline $\begin{array}{l}\text { Do you describe your } \\
\text { goods to your customers? }\end{array}$ & & & & \\
SA & 515 & 48.3 & 48.3 & 48.3 \\
A & 431 & 40.4 & 40.4 & 88.7 \\
SD & 23 & 2.2 & 2.2 & 90.8 \\
D & 22 & 2.1 & 2.1 & 92.9 \\
U & 76 & 7.1 & 7.1 & 100.0 \\
Total & 1067 & 100.0 & 100.0 & \\
\hline Do you leave your buyers & & & & \\
to identify the contents & & & & \\
of your goods? & & & & \\
SA & 352 & 33.0 & 33.0 & 33.0 \\
A & 352 & 33.0 & 33.0 & 66.0 \\
SD & 79 & 7.4 & 7.4 & 73.4 \\
D & 138 & 12.9 & 12.9 & 86.3 \\
U & 146 & 13.7 & 13.7 & 100.0 \\
Total & 1067 & 100.0 & 100.0 & \\
\hline
\end{tabular}




\begin{tabular}{|l|l|l|l|l|}
\hline Can you be an agent for & & & & \\
the sales of goods? & & & & \\
SA & 434 & 40.7 & 40.7 & 40.7 \\
A & 524 & 49.1 & 49.1 & 89.8 \\
SD & 31 & 2.9 & 2.9 & 92.7 \\
D & 14 & 1.3 & 1.3 & 94.0 \\
U & 64 & 6.0 & 6.0 & 100.0 \\
Total & 1067 & 100.0 & 100.0 & \\
\hline Do you accept advance & & & & \\
payment and deliver & & & & \\
goods later? & & & & \\
SA & 327 & 30.6 & 30.6 & 30.6 \\
A & 406 & 38.1 & 38.1 & 68.7 \\
SD & 95 & 8.9 & 8.9 & 77.6 \\
D & 72 & 6.7 & 6.7 & 84.3 \\
U & 167 & 15.7 & 15.7 & 100.0 \\
Total & 1067 & 100.0 & 100.0 & \\
\hline Do you deliver goods and & & & & \\
receive payment later? & & & & \\
& & & & \\
SA & 270 & 25.3 & 25.3 & 25.3 \\
A & 415 & 38.9 & 38.9 & 64.2 \\
SD & 95 & 8.9 & 8.9 & 73.1 \\
D & 78 & 7.3 & 7.3 & 80.4 \\
U & & 19.6 & 19.6 & 100.0 \\
Total & & & \\
& & & & \\
\hline
\end{tabular}




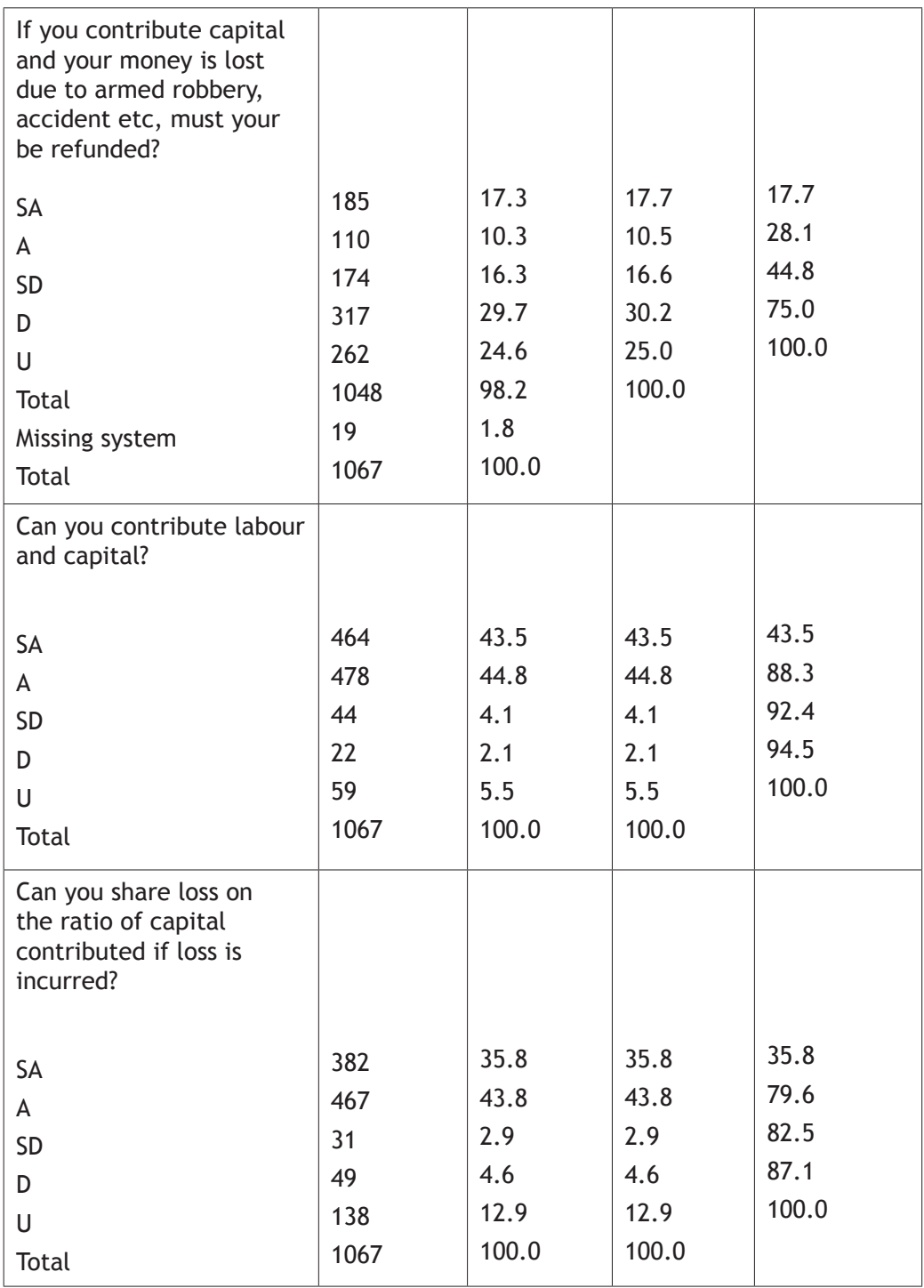

\section{Attitude of respondents to the use of Islamic banking products and services}

Research question four as contained in the appendix: Our respondents were using Islamic products unknowingly. For instance, from Table 4, it could be seen that 947 (88.7 percent) indicated that they described their goods to their customers. In Islam, caveat emptor (let the buyer beware) is not applicable. It is the seller that should make known the conditions of his goods (i.e. caveat venditor). The 
Prophet also said; "He who deceives us is not part of us" (Al-Hafiz, 1996: 286). Specifications are attached to some goods. The implication of this is that buyers need to read them in order to identify the features and contents of such goods. Item 10 was used to elicit information as regards this type of sales. Our respondents (66 percent) indicated that they left their customers to identify the contents of their goods through this medium. Our respondents ( 54.3 percent) offered credit sale to their customer as shown in table 2. Agency is one of the ways by which Islamic financial products are being used. Many of our respondents (89.6 percent) were ready to be agents for capital owners or business owners.

Our respondents also accepted advance payments and delivered goods later. This arrangement is called salam. Our respondents ( 73.2 percent) have been practicing this arrangement. It will not be difficult for them to make use of this Islamic financial product. Bay'un mu'ajjal (delayed payment) is also being practised by them. Our respondents (64.2 percent) delivered goods and received payment later.

Our result shows that our respondents agree to be partners in business. One of the Islamic financial products is to contribute labour and capital for the purpose of carrying on a project or a business. Our respondents ( 88.7 percent) seem to like the arrangement. This may be a result of reducing the risk associated with giving out funds to users and leaving them to make their decisions alone. In this arrangement, both are active partners. They are even ready to share loss based on the ratio of the capital contributed (80.4 percent).

Mudārabah (a financial technique whereby financial and human resources are combined together) is tested by asking our respondents whether they can share loss according to the ratio of capital contributed in the case where the loss is incurred and is not due to negligence of the finance user. It is clear from their response that they are ready to bear such loss (79.6 percent). This is a good indication that Nigerian customers are ready to patronise the products. In the Islamic financial system, the capital owner cannot get his/her money back if there is a loss and the loss is not due to the capital user's negligence. Our respondents (28.1 percent) seemed to be uncomfortable with this arrangement. However, about 26 percent of them did not accept it while another 26 percent could not come to a decision. The implication is that people do not trust others. If the capital user is trusted, the provider of funds may be sympathetic and waive the repayment of such stolen funds or destroyed property. It is one of the principles of mudarabah, that the finance provider bears the loss incurred if the loss is not due to negligence or the fact that the user has gone ultra vires and the finance user loses his labour, energy and time. He is also not entitled to any returns. Another product, Mushārakah, was tested by asking the respondents whether they can contribute both labour and capital. A large number ( 88.3 percent) agreed that they were ready to do that 
with the Islamic bank. The product is a partnership that involves the combination of labour and capital from both the finance provider and the finance user. Our respondents' opinion on salam and bay 'un mua'jjal was sought and we found that 66.7 percent and 64.2 percent of our respondents, respectively, agreed that they would patronise the two products. Salam is a sale in which the price is paid in advance and the commodities are delivered on a specified future date while bay'un тиа'jjal is a deferred payment in which the payment for the inputs or implements sold to the customers by the bank is made later. Our respondents were very comfortable with the two products. Some Islamic products such as 'ijārah and murābahah involve an agency. In the light of this, our respondents were asked whether they would want to be agents. A large number of them ( 89.8 percent) showed their intention to be agents for Islamic banking. This suggests that the success of the bank is sure. 'Ijärah is employment of the services of human beings on wages and utilisation of assets and property on rent while murābahah means cost plus mark-up.

Are people ready to patronise Islamic financial institutions? Items 18 of the questionnaire provided answers to this research question.

Table 5: Patronage of Islamic banking

\begin{tabular}{|l|l|l|l|l|}
\hline & Frequency & Percent & $\begin{array}{c}\text { Valid } \\
\text { Percent }\end{array}$ & $\begin{array}{l}\text { Cumulative } \\
\text { Percent }\end{array}$ \\
\hline $\begin{array}{l}\text { If Shariah financial } \\
\text { institutions are available, } \\
\text { would you support } \\
\text { them and feel more } \\
\text { comfortable? }\end{array}$ & & & & \\
SA & & & & \\
A & 577 & 54.1 & 55.1 & \\
SD & 276 & 25.9 & 26.3 & 85.1 \\
D & 22 & 2.1 & 2.1 & 83.5 \\
U & 37 & 3.5 & 3.5 & 87.0 \\
Total & 136 & 12.7 & 13.0 & 100.0 \\
Missing system & 1048 & 98.2 & 100.0 & \\
Total & 19 & 1.8 & & \\
\hline
\end{tabular}

\section{Patronage of Islamic Banking}

Research question five: Patronage is the foundation of usage of Islamic financial products and services. If the foundation of a building is not strong, the building is 
bound to collapse. In the same vein, if the awareness of the products is not there, patronage of the bank cannot happen. If there is no patronage or it is low the bank may not survive. Interest-free financial institutions may not have problems in getting customers to patronise them. Eight hundred and fifty-three (81.4 percent) of our respondents were ready to do business with them if they are established. This means the environment is conducive for interest-free financial institutions. A very few respondents (5.6 percent) were not ready to patronise Islamic banking even if it is the only banking product in the Nigerian economy

\section{Personal Interview with some Key People}

It was found impossible to use personal interviews and telephone interviews to collect the necessary information needed due to the time and cost constraints. Nevertheless, the researcher still used this method to interview some key people whose views on the issue can serve as a good representation of different groups. For the constraints of finance, space and time, we present the views of one person that are believed to be representative of the views of other people not interviewed. A retired professor of religious studies at the University of Ibadan and an ordained Catholic priest, Rev. Father, Professor Joseph Kenny, was interviewed in his office (10.00 a.m. 9 February, 2011 and 11.00 a.m., 15 June, 2011).

Question:What is your view as regards riba (interest)?

Answer: It has an element of injustice. In fact, if care is not taken, one can be indebted to banks or lenders forever if one takes a loan with interest. In fact, we had to do without borrowing when we were building our offices and classrooms.

"I do not have a bank account. My pension is paid into the account of the community. I have never taken a loan on interest." As regards giving loans without interest, Professor Kenny expressed his fear: "I don't know how that can work. If you give a loan of say, N50,000 to a person and you take the same amount back from him after a year or more, how can the bank employees be paid? Where would you get money to build bank offices?"

\section{Conclusion}

This study provides important information about awareness and attitudes of our respondents, both Muslims and non-Muslims, as regards Islamic banking. The level of their awareness is very low. Islamic banks should promote their presence 
as well as their investment products. They need to invest in advertising both, so that Nigerian customers can consider their products among the extensive variety available in Nigerian financial institutions. Islamic banks should explore various means such as radio, television, workshops, conferences, seminars and the Internet to disseminate information on the operation of Islamic banking. Imams and Islamic preachers should propagate the teachings of Islam on Islamic banking. Non-Muslims should be assured by educational campaigns of non-discrimination if they patronise Islamic banking. Islamic bankers should use simpler words to explain the activities of their banks to non-Muslims and Muslims with a view to making them comprehend their products and services so as to patronise the banks. At present, the banks are restricted to the Northern part of the country. Many branches need to be opened in all the states if the banks are to compete with conventional ones in the country. This will give a large number of people easy access to the bank if they are interested in investing in Islamic banking products and services. Nigeria is an attractive financial market to offer Shariah compliant products and services because of its large population, of which Muslims are in the majority. Islamic banks have a greater chance of being more quickly integrated because many Nigerians are looking for an alternative way of banking. Now that a regulating structure has been put in place by the Central Bank of Nigeria together with other financial Acts, people will have confidence in patronising the banks. New products should be developed to cater to the various needs of existing and potential customers of the banks, both Muslims and non-Muslims.

\section{Recommendations:}

- Islamic banking operators should not discriminate against any person on the basis of religion and ethnicity.

- The government needs to create an enabling environment for the operation of Islamic banking.

- There is a need to develop policies and strategies and the institutional legal framework which will reduce the issues of dishonesty, moral laxity and information asymmetry from the sides of both the Islamic banking operators and their customers.

\section{Notes}

* Kareem Muritala Kawuyemi is a Lecturer at the University of Ibadan. He obtained his B.A. and M. A. in Arabic and Islamic Studies from the University of Ibadan Nigeria, in 1990 and 1995, respectively, where he is also currently completing his Ph.D. 


\section{References}

Alao, D. O. and Alao E. M. (2012). Islamic Banking: The Controversy over NonInterest Banking System in Nigeria. Arabian Journal of Business and Management Review (Nigerian Chapter) Vol. 1, No. 1.

Albarracin, D. et al. (2005). Attitudes: Introduction and Scope in Albarracin, D., Johnson, B., and Zanna, M. (eds.), The Handbook of Attitude. Routledge.

Al-Hafiz b. Hajar al-Asqalani. (1996). Bulughu al-maram part I. Riyadh-Saudi Arabia: Dar-us-Salam publication.

Ali, M.M. (1986). The Religion of Islam. New Delhi: Taj Company.

Anyanwu, J.C.1993. Monetary Economics. Theory, Policy and Institutions. Onitsha: Hybrid Publishers Ltd.

Aristotle n.d. Politics. Book 1 Chapter X 1258. Lahore. Awami Publisher Central Bank of Nigeria official website www.cenbank.org

Egboro, E. M. 2011. Interest Free Banking in Nigeria - Welcome Islamic Banking; Welcome Christian Banking. JORIND 9(2) December 2011. ISSN 1596 - 8308. www.transcampus.org. www.ajol.info/journals/jorind 288.

Ekezie, E.S. (2002) The Elements of Banking. Onitsha: African FEP Publishers Limited

Ekpo, A (1986). Food dependent and the Nigerian Economy: An ex-post analysis, 1960-80. Nigerian Journal Economic and Social Studies.

Fred, K. (1973). Foundation of Behavioural Research. New York: Holt Rinehart and Winston Inc.

Fuad al-Omar and Mohammed, A.H. (1988) Islamic Banking. Karachi: Oxford University Press.

Hornby A.S. 2005. Oxford Advanced Learner's Dictionary. Oxford: Oxford University Press.

International IDEA, 2001. Democracy in Nigeria. Stockholm: International Institute for Democracy and Electoral Assistance.

Kamal N. et al. (2013). Customers Awareness and Satisfaction of Islamic Banking Products and Services: Evidence from the Kuwait Finance House. International Journal of Marketing Studies; Vol. 5, No. 6;

Kareem M.K. (2010): The Development Finance Institution in Nigeria and the Islamic Finance since 1964. Journal of Oriental and African Studies Vol.19.

Khan, M. S. N., Hassan M. K. \& Shahid A. I. (2008). Banking behavior of Islamic bank customers in Bangladesh. Journal of Islamic Economics, Banking and Finance.

Lateh, N., Ismail, S. \& Ariffin, N. M. (2009). Customers“ perceptions on the objectives, characteristics and selection of criteria of Islamic bank in Thailand. Gadjah Mada International Journal of Business, 11(2), 
Lawal, Y.O. Islamic Banking in Nigeria: A Stimulant for Mobilising Funds for Productive Activities American Journal of Social and Management Sciences ISSN Print: 2156-1540, ISSN Online: 2151-1559, doi: 10.5251/ajsms.2012.3.4.132.139 C 2012, Science $\operatorname{Hu} \beta$,

http://www.scihub.org/AJSMS

Okumus, H. S. (2005). Interest-free banking in Turkey: a study of customer satisfaction and bank selection criteria. Journal of Economic Cooperation 26 (4).

Priviledge C. (2014). Awareness of Islamic Banking Products and Services among Consumers in South Africa. Mediterranean Journal of Social Sciences Vol. 5 No: 9.

Rev. Father, Professor Joseph Kenny was interviewed in his office when he was alive (10.00 a.m. 9 February, 2011 and 11.00 a.m. 15 June 2011).

Rammal, H. \& Zurbruegg, R. (2007). Awareness of Islamic banking products among Muslims: The case of Australia. Journal of Financial Services Marketing, 12(1).

Sharafah Y 1985. Gardens of the Righteous. Trans. M. Z. Khan. Beirut. Lebanon: IF.

Thambiah, S., Eze, U. C., Santhapparaj, A. J., \& Arumugam, K. (2011). Customers“ perception of Islamic retail banking: A comparative analysis between the urban and rural regions of Malaysia. International Journal of Business and Management, 6(1).

The three people whose views represent other peoples' responses were Professor (Reverend Father) Joseph Kenny, Magistrate Uthman and Jolaade Misbau.

Vaish, M.C. 2000. Monetary theory. New Delhi: Vikas Publishing house PVT Ltd. 


\section{APPENDIX \\ DEPARTMENT OF ARABIC AND ISLAMIC STUDIES \\ UNIVERSITY OF IBADAN \\ QUESTIONNAIRE ON CUSTOMERS' AWARENESS, ATTITUDE AND \\ PATRONAGE OF ISLAMIC BANKING IN NIGERIA}

\section{Dear Respondents,}

This questionnaire is designed to collect pieces of information on Customers' Awareness, Attitude and Patronage of Islamic Banking in Nigeria. Therefore, the questionnaires are divided into two sections. All the information gathered would be treated with utmost confidentiality. I thank you for filling out this form. Please, respond on time.

\section{SECTION A}

Sex:

Male ( ) Female ( )

Religion: Islam ( ) Christianity ( ) Judais ( ) Others ( )

Type of business:

Ownership status: Owner ( ) Agent ( ) Apprentice ( )

Education: $\quad$ No formal education ( ) Pry Sch. cert. ( ) SSCE ( ) OND/NCE ( ) BA/BSc/HND ( ) Postgraduate ( )

\section{SECTION B}

Please respond to the following questions below using the following:
SA: I strongly agree,
A: I Agree,
SD: I strongly disagree,
D: I disagree,
U: I am undecided

\begin{tabular}{|c|c|c|c|c|c|c|}
\hline & & SA & A & SD & D & $\mathrm{U}$ \\
\hline 1 & Can you take loan without interest & & & & & \\
\hline 2 & Can you accept unlimited liability & & & & & \\
\hline 3 & $\begin{array}{l}\text { If you contribute only capital, can you } \\
\text { share profit and loss }\end{array}$ & & & & & \\
\hline 4 & $\begin{array}{l}\text { Are you ready to expose the secrets of } \\
\text { your business for monitoring }\end{array}$ & & & & & \\
\hline 5 & $\begin{array}{l}\text { Do you keep proper accounts of your } \\
\text { business }\end{array}$ & & & & & \\
\hline 6 & Is your business Shariah compliant & & & & & \\
\hline 7 & $\begin{array}{l}\text { Do you sell pork, alcoholic drinks, dead } \\
\text { animals and their likes }\end{array}$ & & & & & \\
\hline 8 & $\begin{array}{l}\text { Can you give collateral security if you are } \\
\text { given loan }\end{array}$ & & & & & \\
\hline
\end{tabular}




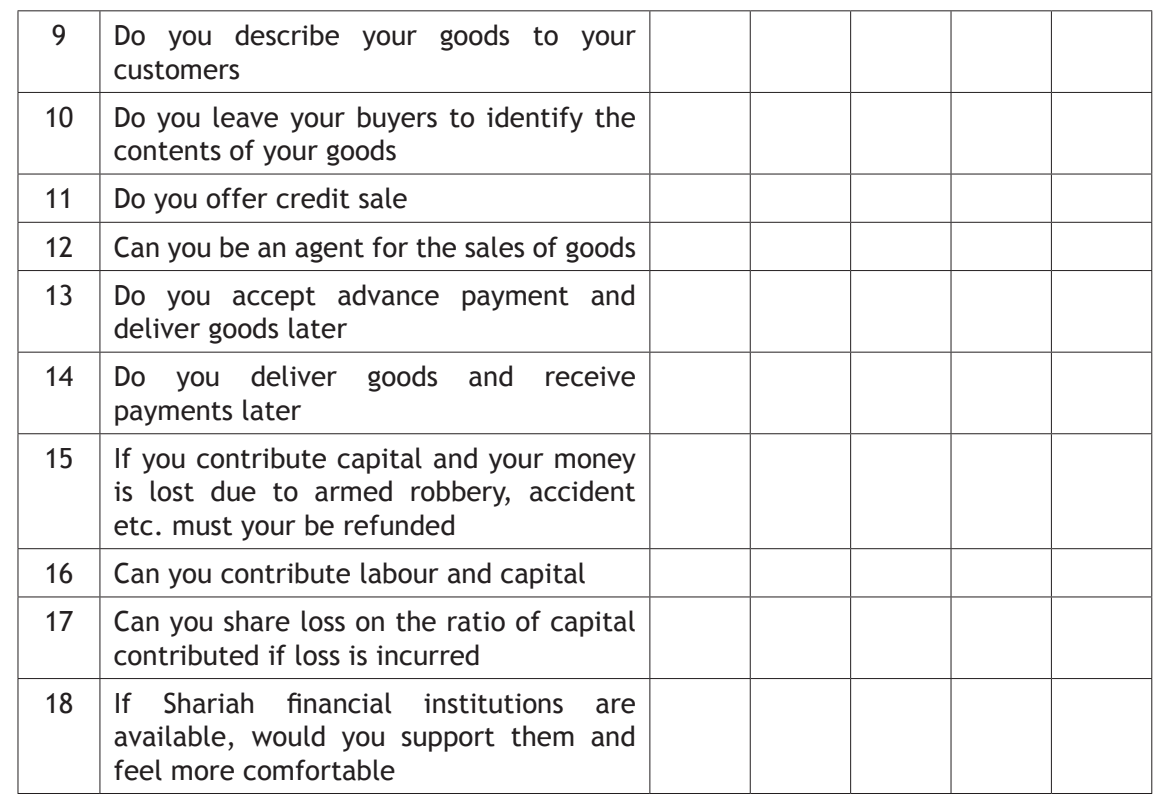

